Research Article

\title{
Synthesis and Characterization of Nanofiber of Oxidized Cellulose from Nata De Coco
}

\author{
Ditpon Kotatha $(\mathbb{D})$ and Supitcha Rungrodnimitchai \\ Department of Chemical Engineering, Faculty of Engineering, Thammasat University, Khlong Luang, \\ Pathum Thani 12120, Thailand \\ Correspondence should be addressed to Supitcha Rungrodnimitchai; supitcha@engr.tu.ac.th
}

Received 9 February 2018; Revised 2 May 2018; Accepted 15 May 2018; Published 2 July 2018

Academic Editor: Michael Harris

Copyright ( 92018 Ditpon Kotatha and Supitcha Rungrodnimitchai. This is an open access article distributed under the Creative Commons Attribution License, which permits unrestricted use, distribution, and reproduction in any medium, provided the original work is properly cited.

\begin{abstract}
Oxidized cellulose (OC) nanofiber was successfully prepared from the dry sheet of Nata De Coco (DNDC) using the mixture system of $\mathrm{HNO}_{3} / \mathrm{H}_{3} \mathrm{PO}_{4}-\mathrm{NaNO}_{2}$ for the first time. The carboxyl content of the $\mathrm{OC}$ was investigated at different conditions $\left(\mathrm{HNO}_{3} / \mathrm{H}_{3} \mathrm{PO}_{4}\right.$ ratios, reaction times, and reaction temperatures). The results revealed that the carboxyl content of the OC increased along with the reaction time, which yielded $0.6,14.8,17.5,20.9,21.0$, and $21.0 \%$ after $0,6,12,36$, and 48 hours, respectively. The reaction yields of the OC ranged between $79 \%$ and $85 \%$ when using $\mathrm{HNO}_{3} / \mathrm{H}_{3} \mathrm{PO}_{4}$ ratio of $1: 3,1.4 \%$ wt of $\mathrm{NaNO}_{2}$ at $30^{\circ} \mathrm{C}$ at different reaction times. From the structural analysis, the OC products showed a nanofibrous structure with a diameter of about 58.3-65.4 nm. The Fourier transform infrared spectra suggested the formation of carboxyl groups in the OC after oxidation reaction. The crystallinity and crystalline index decreased with an increase of reaction time. The decrease of crystallinity from oxidation process agreed with the decrease of degree of polymerization from the hydrolysis of $\beta$-1,4-glycosidic linkages in the cellulose structure. The thermal gravimetric analysis results revealed that the OC products were less thermally stable than the raw material of DNDC. In addition, the OC products showed blood agglutinating property by dropping blood on the sample along with excellent antibacterial activity.
\end{abstract}

\section{Introduction}

Oxidized cellulose (OC), which could be obtained by partial oxidation of the hydroxymethyl groups on the hydroglucose rings to produce cellulose containing carboxyl group (Figure 1), is an important biocompatible polymer. It has hemostatic property and has been widely used in medical researches and surgery; for example, it was used as hemostatic agents in cardiac surgery [1], thyroid surgery [2], laparoscopic surgery for small uterine perforation [3], and it was used for tubal hemorrhage hemostasis during laparoscopic sterilization [4]. Moreover, it can also be used as drug delivery materials [5] and heavy metal adsorbents [6, 7].

Due to special applications of the OC, many researchers have been trying to synthesize OC, for example, by reactions with oxidizing reagents such as nitrogen dioxide $[8,9]$, the mixture of nitric acid, phosphoric acid, and sodium nitrite
$[10,11]$, or reaction with relatively less unstable nitroxyl radical reagents such as 2,2,6,6-tetramethylpiperidine $\mathrm{N}$ oxyl (TEMPO) [12-14].

However, almost all of reports use cellulose from the plant or viscose fiber with a diameter about $10-20 \mu \mathrm{m}$ [15] as raw material. It was reported that Nata De Coco is a nanofiber of bacterial cellulose with about $30-70 \mathrm{~nm}$ in diameter [16-18] and able to absorb 200 times of water of its original weight [19]. Furthermore, the nanofiber was reported for its super functionalities for various applications such as optically and transparently functional materials, tissue engineering scaffolds, food package, catalysts, textiles, or surface coatings [20-24]. Therefore, if Nata De Coco is used as a raw material for OC, it possibly can produce higher oxidation efficiency or different properties than previous reports.

Nowadays, Nata De Coco is a well-known food product, which is served as a dessert by cutting in the form of cubes 


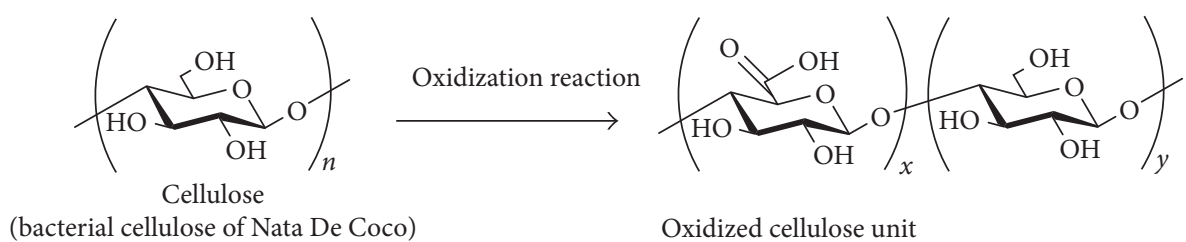

Figure 1: Oxidation reaction of cellulose.

and boiling in syrup. The Nata De Coco is produced by the fermentation of coconut juice, which gels through the production of microbial cellulose that can produce acetic acid such as Pseudomonas sp., Alcaligenes sp., Agrobacterium sp., Rhizobium sp., and the most common one is Acetobacter xylimum [25]. Moreover, it can be produced from the other sources of sugar such as fruit juices (orange, pineapple, apple, Japanese pear, and grape juices) [26], coconut milk, milk serum, and molasses which is a by-product of sugarcane refining. It is a natural nanofiber which was produced at low costs. If Nata De Coco can be used as raw materials to synthesize OC nanofiber, then nanofibers of other cellulose derivatives would be able to be prepared from Nata De Coco as well.

In this work, the OC nanofiber was synthesized from the dry sheet of Nata De Coco (DNDC) for the first time by a mixture of the $\mathrm{HNO}_{3} / \mathrm{H}_{3} \mathrm{PO}_{4}-\mathrm{NaNO}_{2}$ system. The properties and characterization of the novel OC and its blood agglutination and antibacterial activity properties were discussed.

\section{Materials and Methods}

2.1. Materials. Nata De Coco of food grade was purchased from a local market in Pathumthani province, Thailand. The nature cotton linter was purchased from a cotton mill in Sakonnakhon province, Thailand. Nitric acid (65.0\%), orthophosphoric (85.0\%), sodium nitrite $(97.0 \%)$, calcium acetate $(99.0 \%)$, sodium hydroxide $(98.0 \%)$, and ethanol (99.9\%) were purchased from Carlo Erba. Copper(II)ethylenediamine complex (1 M solution in water) was purchased from Acros. All chemicals were of reagent grade or analytical grade and used as received.

2.2. Preparation of Raw Material. Nata De Coco $(1,600 \mathrm{~g})$ in the form of $1 \mathrm{~cm}$ cubes was washed in distilled water. Subsequently, it was cut and ground in a cooking mixture for 3 minutes and was filtered for removing water. Then, the solid residue was poured into a tray $(34 \times 25 \mathrm{~cm})$ and was dried at $60^{\circ} \mathrm{C}$ for 48 hours. After that, the DNDC was cut to $1 \times 1 \mathrm{~cm}$ size and then used as a raw material.

2.3. Synthesis of OC. Approximately $2.0 \mathrm{~g}$ of dry Nata De Coco was added to $50 \mathrm{~mL}$ of $\mathrm{HNO}_{3} / \mathrm{H}_{3} \mathrm{PO}_{4}$ mixture in a glass bottle with the ratios of $1: 1,2: 1,1: 2,1: 3$, and $1: 4(\mathrm{v} / \mathrm{v})$. Subsequently, $\mathrm{NaNO}_{2}$ was added with amounts of 1.0, 1.4, 1.8 , and $2.2 \%(\mathrm{w} / \mathrm{v})$. The reddish fumes instantaneously occurred. The glass bottle was capped and let to react at 10 , 20,30 , and $40^{\circ} \mathrm{C}$ for $6,12,24,36$, and 48 hours, respectively, with a shaking speed of $100 \mathrm{rpm}$ in a water bath shaker. The obtained samples were washed with distilled water until the filtrate reached a pH of about 4 . It was then washed with $50 \%$ $\mathrm{v} / \mathrm{v}$ ethanol and finally washed with distilled water again. The OC was air dried at room temperature before characterization and the $\%$ yield was determined using the following equation:

$$
\% \text { yield }=\frac{\text { dry weight of the OC }(\mathrm{g})}{\text { dry weight of Nata De Coco }(\mathrm{g})} \times 100 .
$$

2.4. Determination of Carboxyl Content. The carboxyl content was measured in accordance with the United States Pharmacopeia (USP23-NF18) [27]. The sample $(0.5 \mathrm{~g})$ with a known amount of the moisture content was added in $50 \mathrm{~mL}$ of $2 \%$ calcium acetate solution and shaken in the water bath shaker with a shaking speed of $100 \mathrm{rpm}$ for 12 hours. After that, the mixture was titrated with $0.1 \mathrm{~N} \cdot \mathrm{NaOH}$ standard solutions by using phenolphthalein as an indicator. The volume of the consumed $\mathrm{NaOH}$ was corrected by the blank. The carboxyl content was determined using the following equation:

$$
\% \text { carboxyl content }=\frac{\mathrm{N} \times \mathrm{V} \times \mathrm{MW}_{-\mathrm{COOH}}}{\mathrm{m}} \times 100,
$$

where $\mathrm{N}$ is the normality of $\mathrm{NaOH}, \mathrm{V}$ is the volume of $\mathrm{NaOH}$ used in titration, $\mathrm{MW}_{-\mathrm{COOH}}$ is the molecular weight of carboxyl group, and $\mathrm{m}$ is the weight of the dry testing sample (mg).

2.5. Fourier Transform Infrared Spectrometry (FT-IR). Fourier transform infrared imaging microscopy (Perkin Elmer; model: Spectrum Spotlight 300) was used for identification of functional groups of the obtained samples by micro-attenuated total reflectance technique. All FT-IR spectra were scanned with a resolution of $1 \mathrm{~cm}^{-1}$ in the range of $4000-400 \mathrm{~cm}^{-1}$.

2.6. Morphology Analysis. The scanning electron microscopy (SEM, Hitashi model S-3400N) was used for analysis of the morphology of the fiber at $10 \mathrm{kV}$ with $10 \mathrm{k}$ magnification, and the diameter and size distribution of the fiber were analyzed by using image visualization software (Image-Pro Plus). The samples were coated with gold vapor before observation.

2.7. X-Ray Diffraction (XRD) Analysis. XRD patterns of the obtained samples were recorded using an X-ray 

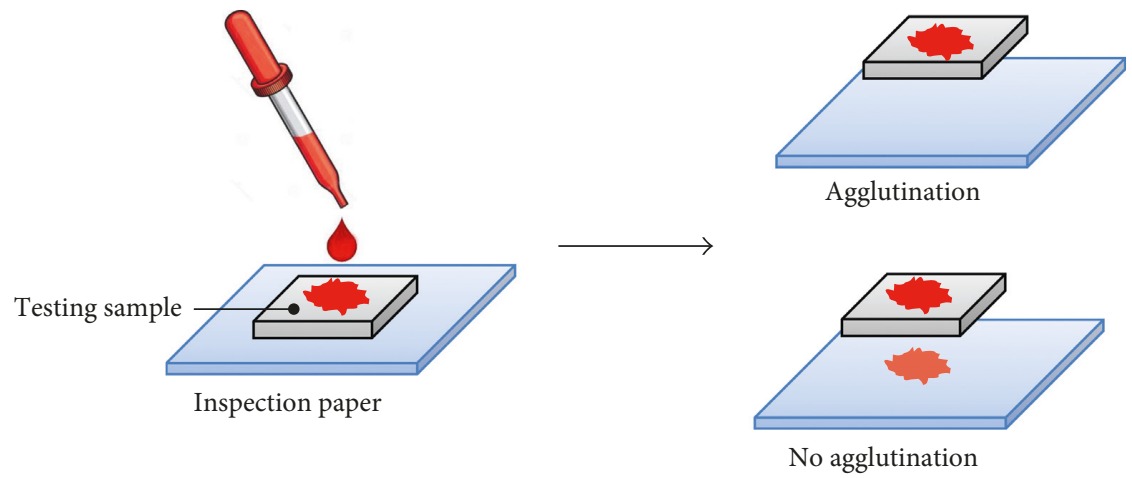

Figure 2: A schematic diagram of the blood agglutination test.

diffractometer (PANalytical, model: X'Pert Pro). The samples were scanned from $3^{\circ}$ to $40^{\circ}$ of $2 \theta$ in $0.02^{\circ}$ step per 0.5 seconds, and the operating voltage and current was $40 \mathrm{kV}$ and $30 \mathrm{~mA}$, respectively. The radiation was $\mathrm{Ni}$-filtered $\mathrm{Cu}-\mathrm{Ka}$ radiation of wavelength $1.54 \AA$. The crystallinity degree $\left(\mathrm{X}_{\mathrm{c}}\right)$ and crystalline index (CrI) of the obtained samples were estimated by following the literatures $[11,28]$ as per the following equation:

$$
\begin{aligned}
& X_{\mathrm{c}}=\frac{S_{\mathrm{c}}}{S_{\mathrm{c}}+S_{\mathrm{a}}} \times 100, \\
& \mathrm{CrI}=\frac{I_{\left(\begin{array}{lll}
0 & 2 & 2
\end{array}\right)}-I_{\mathrm{AM}}}{I_{\left(\begin{array}{lll}
0 & 0 & 2
\end{array}\right)}} \times 100,
\end{aligned}
$$

where $S_{c}$ is the sum of all crystal areas and $S_{a}$ is the amorphous area. $I_{\left(\begin{array}{ll}02 \\ 2\end{array}\right)}$ is the maximum intensity of the (lll 0 2 2) lattice diffraction which is the peak around $22^{\circ}$ of $2 \theta$ and $I_{\mathrm{AM}}$ is the diffraction intensity of the amorphous peak around $18^{\circ}$ of $2 \theta$.

2.8. Degree of Polymerization (DP). The degrees of polymerization (DP) of the obtained samples were estimated by the intrinsic viscosity method using a Cannon-Fanske calibrated viscometer (size 75) according to the standard test method for intrinsic viscosity of cellulose (ASTM D1795-96) [29]. The intrinsic viscosity measurement was performed as follows. The sample with a known amount of moisture content varying between 0.2 and $1.0 \mathrm{~g}$ was suspended in $25 \mathrm{~mL}$ of distilled water in a $125 \mathrm{~mL}$ Erlenmeyer flask. The suspension was flushed with nitrogen to remove entrapped air from the sample. After that, $25 \mathrm{~mL}$ of $1.0 \mathrm{M}$ copper(II)ethylenediamine complex (Cuen solution) was added into the suspension and continued flushing with nitrogen about $2 \mathrm{~min}$. The Erlenmeyer flask was then closed with a stopper and shaken in water bath shaker for 24 hours with a shaking speed of $100 \mathrm{rpm}$. After the suspension completely dissolved in the solution, $7 \mathrm{~mL}$ of solution was added to the viscometer in a water bath at $25 \pm 0.5^{\circ} \mathrm{C}$. When the solution reached temperature equilibrium with the bath (in about 5 minutes), the efflux time for the solution between the two marks was measured. The same procedure was employed to measure the efflux time for the $0.5 \mathrm{M}$ Cuen solution.

The intrinsic viscosity $[\eta]$ was calculated using the Martin equation:

$$
\log \left(\frac{\eta_{\mathrm{rel}}-1}{\mathrm{c}}\right)=\log [\eta]+k[\eta] \mathrm{c}
$$

where $\log \left[\left(\eta_{\text {rel }}-1\right) / c\right]$ is plotted against $c$ and the straight line is extrapolated through the point to $c=0$. The intercept gives $\log [\eta]$, where $c$ is the concentration of the sample in $\mathrm{g} / 100 \mathrm{~mL}$ and $\eta_{\text {rel }}$ is the relative viscosity calculated by dividing the efflux time of solution by the efflux time of $0.5 \mathrm{M}$ Cuen solution as given in the following relationship:

$$
\eta_{\text {rel }}=\frac{\eta_{\text {solution }}}{\eta_{\text {solvent }}}=\frac{\text { efflux time }}{\text { solution }_{\text {efflux time }}}
$$

The DP was determined from the following equation:

$$
\mathrm{DP}=[\eta] 190 .
$$

2.9. Thermal Gravimetric Analysis (TGA). The thermal gravimetric analyzer (Mettler Toledo; model: TGA/SDTA $851^{\mathrm{e}}$ ) was used for analysis of the thermal property of the obtained samples. The samples were run at a heating rate of $20^{\circ} \mathrm{C} / \mathrm{min}$ in the range $25-1000^{\circ} \mathrm{C}$ under the nitrogen atmosphere.

2.10. Agglutination of Blood on the OC. The blood agglutination test was adapted from the procedure of Khatei et. al. [30], Jarujamrus et al. [31], and Li et al. [32]. The testing samples of DNDC and the obtained OC were cut to $0.5 \times 0.5 \mathrm{~cm}$ sizes and were placed on an inspection paper. Then, a drop of blood sample was placed on the testing samples and was let to stand for 10 minutes. If the blood stain was not found on the inspection paper after removing the testing sample, it can be concluded that the testing sample have the agglutinated blood property. A schematic diagram of the blood agglutination test is shown in Figure 2.

2.11. Antibacterial Activity. The antibacterial activity of DNDC and the obtained OC was evaluated according to the standard test method for determining the antimicrobial activity of immobilized antimicrobial agents under dynamic control conditions (ASTM E2149) [33]. Gram-negative 
TABle 1: The conditions for synthesis of OC.

\begin{tabular}{|c|c|c|c|c|c|}
\hline Sample name & Material & $\begin{array}{c}\text { Ratios of } \\
\mathrm{HNO}_{3} / \mathrm{H}_{3} \mathrm{PO}_{4}(\mathrm{v} / \mathrm{v})\end{array}$ & $\begin{array}{c}\text { Amount of } \\
\mathrm{NaNO}_{2}(\% \mathrm{w} / \mathrm{v})\end{array}$ & Temperature $\left({ }^{\circ} \mathrm{C}\right)$ & $\begin{array}{c}\text { Reaction time } \\
\text { (hours) }\end{array}$ \\
\hline A0 (DNDC) & DNDC (raw material) & - & - & - & - \\
\hline A1 & \multirow{5}{*}{ DNDC } & $1: 1$ & \multirow{5}{*}{1.4} & \multirow{5}{*}{30} & \multirow{5}{*}{24} \\
\hline $\mathrm{A} 2$ & & $2: 1$ & & & \\
\hline A3 & & $1: 2$ & & & \\
\hline A4 (OC-24 hrs) & & $1: 3$ & & & \\
\hline A5 & & $1: 4$ & & & \\
\hline B1 & \multirow{3}{*}{ DNDC } & \multirow{3}{*}{$1: 3$} & 1.0 & \multirow{3}{*}{30} & \multirow[t]{3}{*}{24} \\
\hline B2 & & & 1.8 & & \\
\hline B3 & & & 2.2 & & \\
\hline $\mathrm{C} 1$ & \multirow{4}{*}{ DNDC } & \multirow{4}{*}{$1: 3$} & \multirow{4}{*}{1.4} & 10 & \multirow{4}{*}{24} \\
\hline $\mathrm{C} 2$ & & & & 20 & \\
\hline $\mathrm{C} 3$ & & & & 40 & \\
\hline $\mathrm{C} 4$ & & & & 50 & \\
\hline D1 (OC-6 hrs) & \multirow{4}{*}{ DNDC } & \multirow{4}{*}{$1: 3$} & \multirow{4}{*}{1.4} & \multirow{4}{*}{30} & 6 \\
\hline D2 (OC-12 hrs) & & & & & 12 \\
\hline D3 (OC-36 hrs) & & & & & 36 \\
\hline D4 (OC-48 hrs) & & & & & 48 \\
\hline F0 & $\begin{array}{l}\text { Natural cotton linter } \\
\quad \text { (raw material) }\end{array}$ & - & - & - & - \\
\hline F1 & \multirow{5}{*}{ Natural cotton linter } & \multirow{5}{*}{$1: 3$} & \multirow{5}{*}{1.4} & \multirow{5}{*}{30} & 6 \\
\hline $\mathrm{F} 2$ & & & & & 12 \\
\hline F3 & & & & & 24 \\
\hline $\mathrm{F} 4$ & & & & & 36 \\
\hline F5 & & & & & 48 \\
\hline
\end{tabular}

bacterium, Escherichia coli ATCC 25922, was used as a test organism. Briefly, the testing samples and a control were placed in sterile glass flasks. Escherichia coli (ATCC 25922) was grown overnight and was diluted to $1.59 \times 10^{5} \mathrm{CFU} / \mathrm{mL}$, and then it was added to the flask. Bacteria recovery at the start of the test $(t=0)$ was determined. The flasks were then shaken for 1 hour after which a small volume of the suspension is reanalyzed for the activity of the leached antimicrobial treatment. Plates were incubated at $37^{\circ} \mathrm{C}$ for 24 hours, and any resulting colonies were counted. The antimicrobial activity was determined in accordance with the standard.

\section{Results and Discussion}

3.1. Reaction Conditions. In this study, $\mathrm{OC}$ was synthesized from DNDC via a mixture of the $\mathrm{HNO}_{3} / \mathrm{H}_{3} \mathrm{PO}_{4}-\mathrm{NaNO}_{2}$ system with different conditions. In addition, the natural cotton linter was also used for synthesis of OC in order to investigate the effect of fiber size of oxidation efficiency. The varied conditions in this experiment are shown in Table 1.

3.2. Carboxyl Content. First of all, the effect of ratios of $\mathrm{HNO}_{3} / \mathrm{H}_{3} \mathrm{PO}_{4}$ on the carboxyl content was investigated. The carboxyl content of the OC products by using different ratios of $\mathrm{HNO}_{3} / \mathrm{H}_{3} \mathrm{PO}_{4}$, which are the reactions performed at $30^{\circ} \mathrm{C}$ and $1.4 \%(\mathrm{w} / \mathrm{v})$ of $\mathrm{NaNO}_{2}$ for 24 hours, are shown in Figure 3. All of reactions yielded OC products after the oxidation reaction with high \% carboxyl content (14.10-20.93\%). The reaction which was obtained by $\mathrm{HNO}_{3} / \mathrm{H}_{3} \mathrm{PO}_{4}=1: 3$ (A4) gave the maximum of carboxyl content as $20.93 \%$, and then the reaction with $\mathrm{HNO}_{3} / \mathrm{H}_{3} \mathrm{PO}_{4}$ ratio of $1: 3$ was chosen for the condition in the further steps.

The effect of amount of $\mathrm{NaNO}_{2}$ on the carboxyl content of the $\mathrm{OC}$ is shown in Figure 4 . The reactions were performed at $30^{\circ} \mathrm{C}$ for 24 hours by using $\mathrm{HNO}_{3} / \mathrm{H}_{3} \mathrm{PO}_{4}=1: 3$ of acid mixture with different amounts of $\mathrm{NaNO}_{2}$. The result showed that the different amounts of $\mathrm{NaNO}_{2}$ gave no significant difference. Moreover, the more vigorous reactions were observed when the amount of $\mathrm{NaNO}_{2}$ was larger than $1.4 \% \mathrm{w} / \mathrm{v}$ (more of reddish fume and bubble were generated), and the bubble overflowed the glass bottle when more than $2.2 \% \mathrm{w} / \mathrm{v}$ of $\mathrm{NaNO}_{2}$ was added. The amount of $\mathrm{NaNO}_{2}$ did not have large effect on the generation of nitrogen oxide because it worked as an initiator. Therefore, condition with $1.4 \% \mathrm{NaNO}_{2}$ was chosen for the condition in the further reaction.

The effect of temperature on the carboxyl content of the OC is shown in Figure 5. Each reaction was performed at different temperatures by using $\mathrm{HNO}_{3} / \mathrm{H}_{3} \mathrm{PO}_{4}=1: 3$ of acid mixture and $1.4 \%$ (w/v) of $\mathrm{NaNO}_{2}$ for 24 hours. The results showed that the carboxyl content increased when the reaction temperature increased from 10 to $30^{\circ} \mathrm{C}$, suggesting that an increase of oxidation rate resulted from an increase of temperature. However, the carboxyl content decreased when the temperature rose up from 30 to $50^{\circ} \mathrm{C}$, which was possibly caused by hydrolysis of 


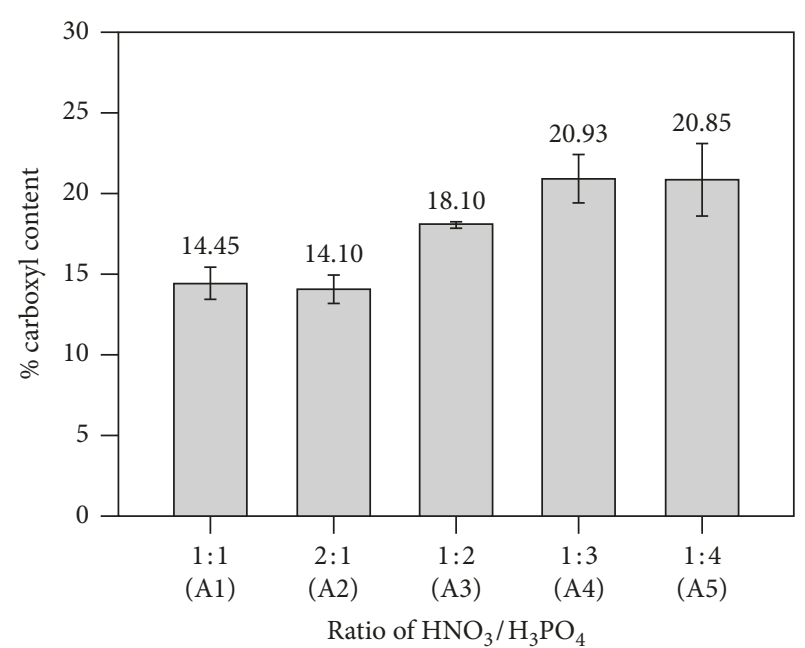

FIGURE 3: Effect of different ratios of $\mathrm{HNO}_{3} / \mathrm{H}_{3} \mathrm{PO}_{4}$ on the carboxyl content of the OC. The reactions were performed at $30^{\circ} \mathrm{C}$ and $1.4 \%$ (w/v) of $\mathrm{NaNO}_{2}$ for 24 hours.

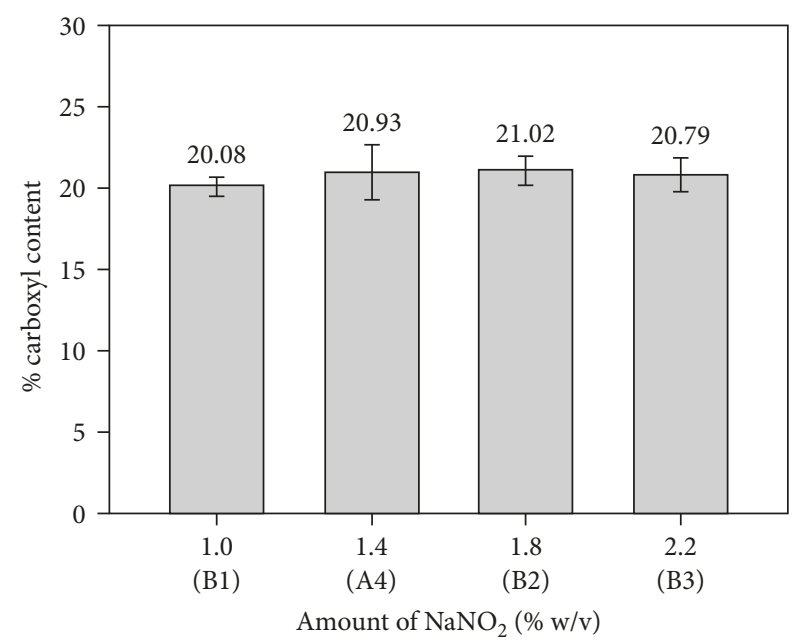

Figure 4: Effect of amount of $\mathrm{NaNO}_{2}$ on the carboxyl content of the OC. The reactions were performed at $30^{\circ} \mathrm{C}$ for 24 hours by using $\mathrm{HNO}_{3} / \mathrm{H}_{3} \mathrm{PO}_{4}=1: 3$ of acid mixture.

cellulose from strong acid. From the results, it could be concluded that $30^{\circ} \mathrm{C}$ was the optimum temperature for the reaction, which yielded the maximum of carboxyl content.

The effect of reaction times on the carboxyl content and $\%$ yield of the OC is shown in Figure 6(a). The OC products were prepared at $30^{\circ} \mathrm{C}$ by using $\mathrm{HNO}_{3} / \mathrm{H}_{3} \mathrm{PO}_{4}=1: 3$ of acid mixture and $1.4 \%(\mathrm{w} / \mathrm{v})$ of $\mathrm{NaNO}_{2}$ for $6,12,24,36$, and 48 hours (the corresponding products were labelled as OC$6 \mathrm{hrs}$ (D1), OC-12 hrs (D2), OC-24hrs (A4), OC-36 hrs (D3), and OC-48 hrs (D4), resp.). The carboxyl content of the raw material of Nata De Coco was $0.57 \%$. On the contrary, the carboxyl content of the OC products as OC$6 \mathrm{hrs}$ (D1), OC-12 hrs (D2), OC-24 hrs (A4), OC-36 hrs (D3), and OC-48 hrs (D4) was 14.79, 17.49, 20.93, 20.96, and $20.98 \%$, and the $\%$ yield was $85.34,84.70,83.19,80.36$, and $78.62 \%$, respectively. The carboxyl content increased with an

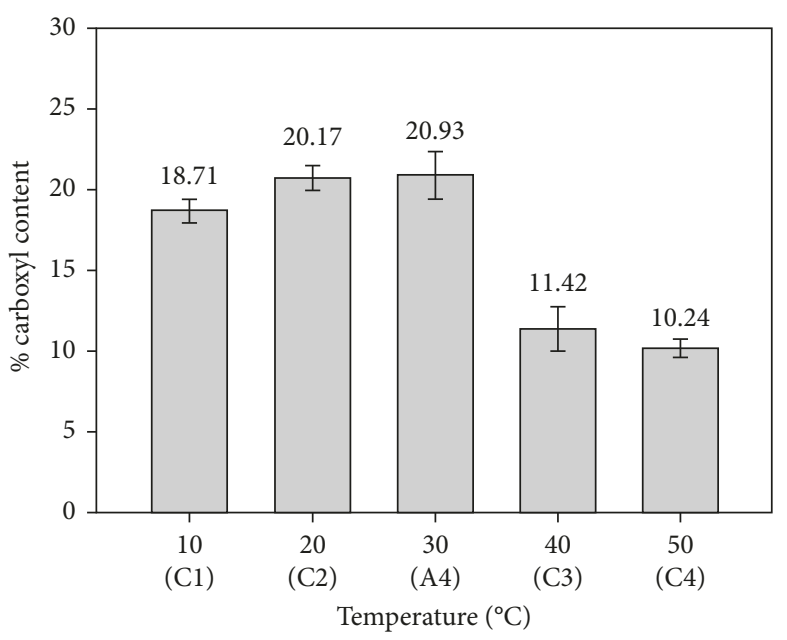

FIgURE 5: Effect of temperature on the carboxyl content of the OC. The reaction using $\mathrm{HNO}_{3} / \mathrm{H}_{3} \mathrm{PO}_{4}=1: 3$ of acid mixture and $1.4 \%$ $(\mathrm{w} / \mathrm{v})$ of $\mathrm{NaNO}_{2}$ for 24 hours.

increase of reaction time, while the $\%$ yield decreased with an increase of reaction time. However, after 24 hours, the results showed that the carboxyl content slightly increased ( 20.93 to $20.98 \%$ from 24 to 48 hours), whereas the $\%$ yield still linearly decreased. It suggested that the reaction at $30^{\circ} \mathrm{C}$ by using $1: 3 \mathrm{HNO}_{3} / \mathrm{H}_{3} \mathrm{PO}_{4}$ of acid mixture and $1.4 \%(\mathrm{w} / \mathrm{v})$ of $\mathrm{NaNO}_{2}$ for 24 hours was the optimum condition for synthesis of the OC with high carboxyl content.

Moreover, the results from preparation of the OC from the natural cotton linter using the same condition as DNDC are shown in Figure 6(b). The tendency of the change of the carboxyl contents and \% yields were similar to those of the OC products from DNDC, but the values were much less than those of the OC products from DNDC. From 6 to 48 hours of reaction times, the OC products from DNDC contained $14.79-20.98 \%$ of the carboxyl content and $85.3-78.6 \%$ of the $\%$ yield. On the contrary, the OC products from the natural cotton linter have the carboxyl content ranging from 8.60 to $10.77 \%$ and \% yield ranging from 78.2 to $45.0 \%$. The result implied that the diameter of the fiber has a great effect on carboxyl contents and \% yields of the OC product. It was presumed that the mixture of acid $\left(\mathrm{HNO}_{3} / \mathrm{H}_{3} \mathrm{PO}_{4}-\mathrm{NaNO}_{2}\right)$ in this system is responsible for the oxidation reaction of cellulose, but excess amount of the acid mixture led to the hydrolysis reaction of cellulose. In DNDC case, the DNDC showed a nanofibrous structure with high surface for oxidation reaction so that almost all of acid mixture was involved in the oxidation reaction, while the fiber of natural cotton showed diameter larger than DNDC (see in morphology analysis) which is a small surface area for oxidation reaction so the amount of free mixture acid is very much remaining. It led to the hydrolysis reaction of the fiber, in which the \% yield was consistent with the carboxyl content.

3.3. Fourier Transform Infrared Spectrometry (FT-IR) Characterization. The FT-IR spectra of microcrystalline 


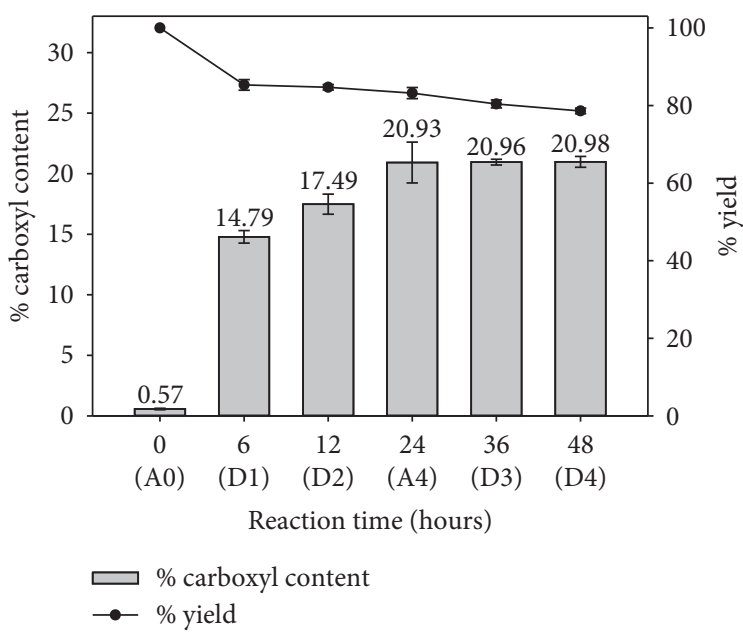

(a)

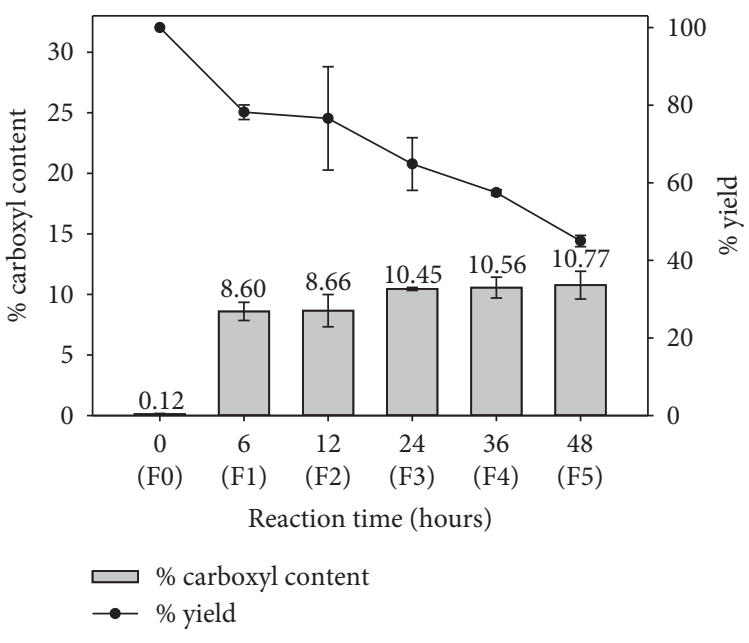

(b)

FIGURE 6: Effect of reaction time on the carboxyl content and \% yield of the OC products from (a) DNDC and (b) natural cotton linter. The reaction was performed at $30^{\circ} \mathrm{C}$ by using $1: 3 \mathrm{HNO}_{3} / \mathrm{H}_{3} \mathrm{PO}_{4}$ mixture and $1.4 \%(\mathrm{w} / \mathrm{v})$ of $\mathrm{NaNO}_{2}$.

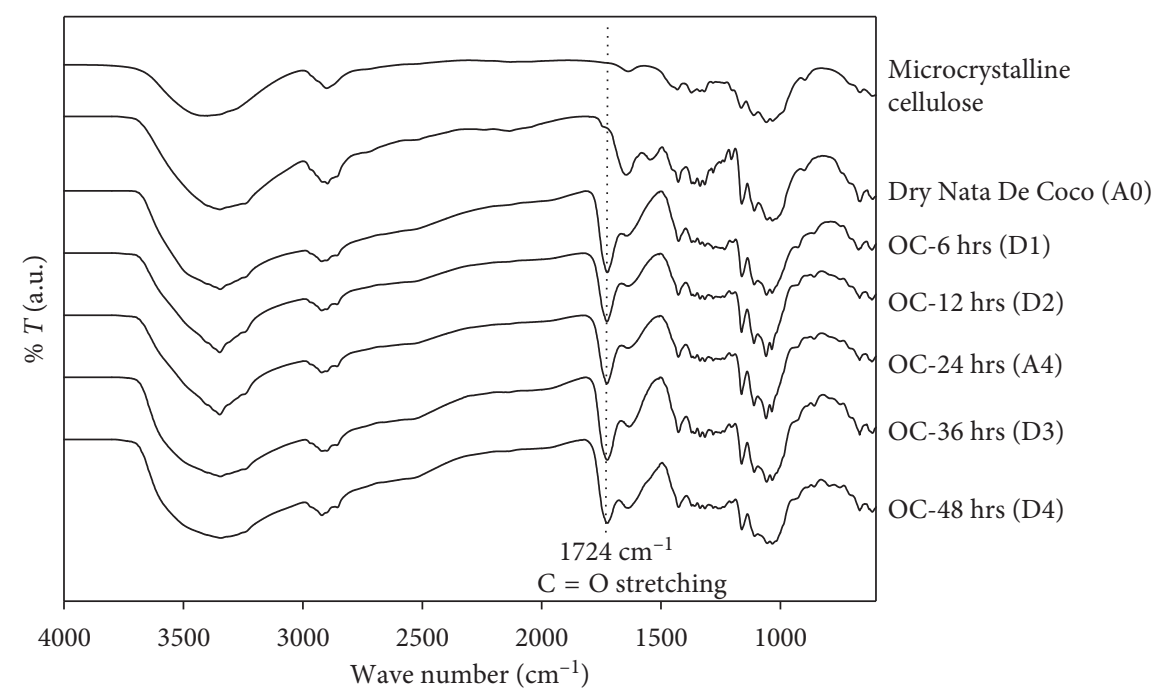

FiguRE 7: FT-IR spectra of microcrystalline cellulose, DNDC (A0), and the OC products.

cellulose (commercial), DNDC (A0), and the OC products are shown in Figure 7 . The absorption peak at $3350 \mathrm{~cm}^{-1}$ corresponded to the stretching vibration of $\mathrm{O}-\mathrm{H}$, and the weak peaks at 2920 and $2850 \mathrm{~cm}^{-1}$ were induced by stretching vibration of $-\mathrm{CH}_{2}$. The several peaks at 1430 to $1200 \mathrm{~cm}^{-1}$ were due to the stretching of $\mathrm{C}-\mathrm{H}$, and peak about 1060 and $1035 \mathrm{~cm}^{-1}$ were due to the stretching of $\mathrm{C}-\mathrm{O}-\mathrm{C}$. These absorption peaks are characteristic of cellulose, while the absorption peak at $1640 \mathrm{~cm}^{-1}$ was related to the $\mathrm{H}_{2} \mathrm{O}$ bending vibration of the adsorbed water of the material. The FT-IR spectra of the OC products were similar to those of microcrystalline cellulose and DNDC (A0), except that all of the OC products showed a new absorption peak at $1724 \mathrm{~cm}^{-1}$, which corresponded to the vibration of carbonyl group $(-\mathrm{C}=\mathrm{O})$, suggesting the formation of carboxyl groups in the products.
3.4. Morphology Analysis. In this research, the morphology of the fiber of the DNDC (A0) and the OC products were analyzed by scanning electron microscopy (SEM) at $10 \mathrm{kV}$ with 10 and $35 \mathrm{k}$ magnification and then, the diameter and size distribution of the fiber were analyzed by using image visualization software (Image-Pro Plus) from the SEM images.

The $10 \mathrm{k}$ magnification of SEM images and diameter size distribution from SEM images of DNDC (A0) and the OC products are shown in Figure 8, and higher magnification of SEM images (35k) of DNDC (A0) and OC-24 hrs (A4) are shown in Figure 9. SEM images of DNDC (A0) (Figure 8(a)) revealed a nanofibrous structure, and average diameter size was about $69.8 \mathrm{~nm}$ which is similar with the previous reports $[16,17]$. Moreover, the diameter of the OC products as OC$6 \mathrm{hrs}$ (D1), OC-12 hrs (D2), OC-24 hrs (A4), OC-36 hrs (D3), 

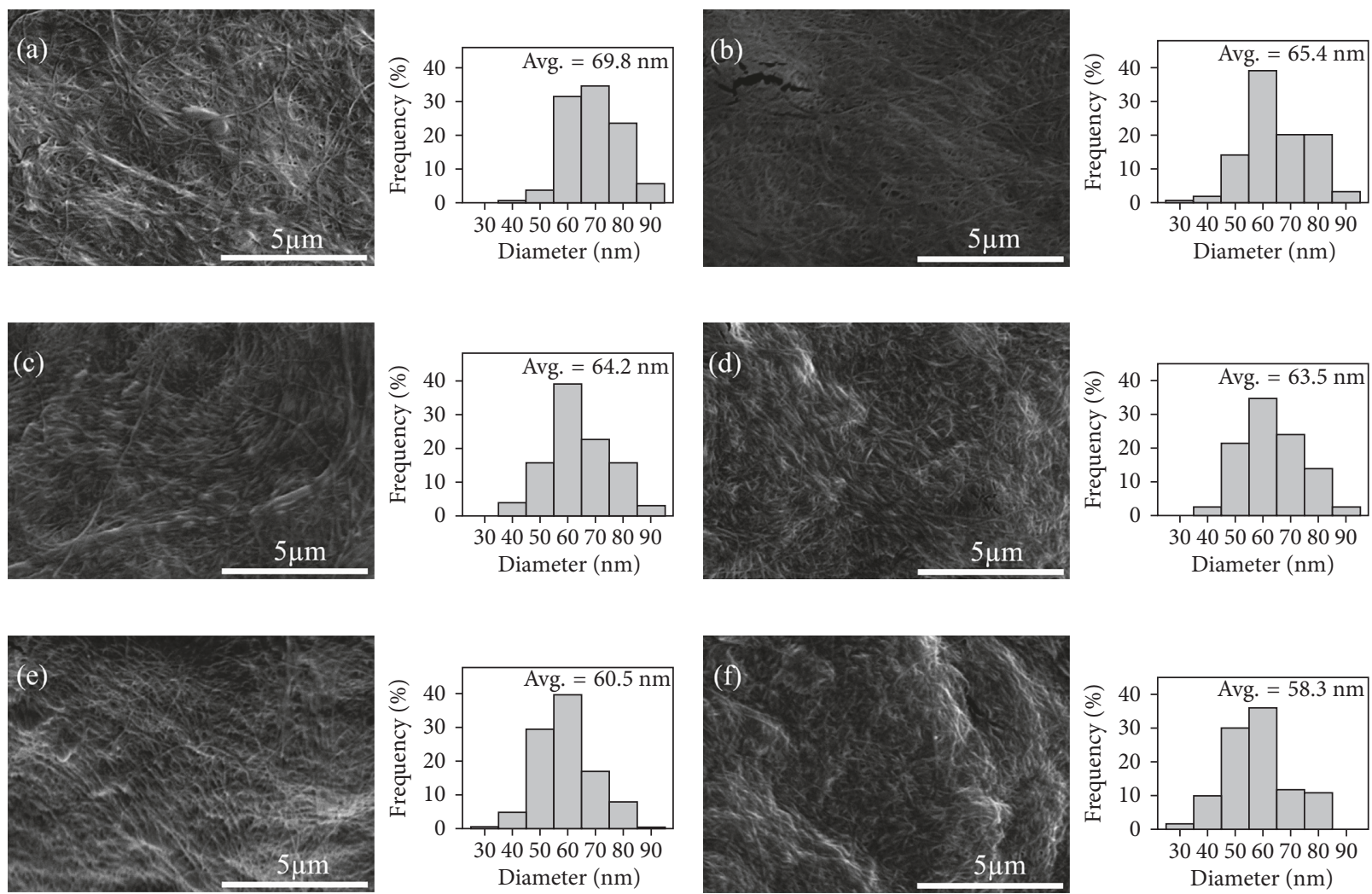

Figure 8: $10 \mathrm{k}$ magnification of SEM images of (a) DNDC (A0), (b) OC-6 hrs (D1), (c) OC-12 hrs (D2), (d) OC-24 hrs (A4), (e) OC-36 hrs (D3), and (f) OC-48 hrs (D4) and their diameter size distribution.

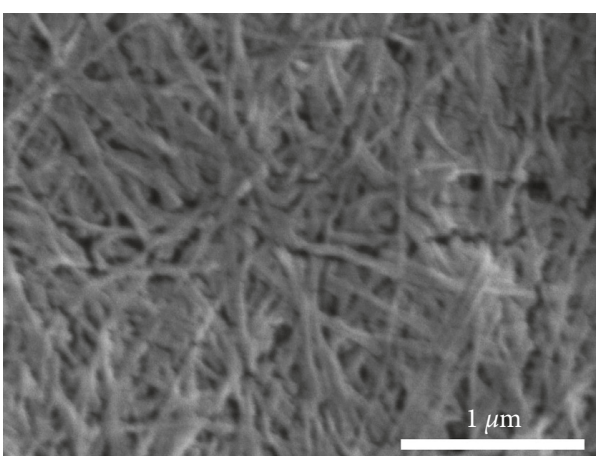

(a)

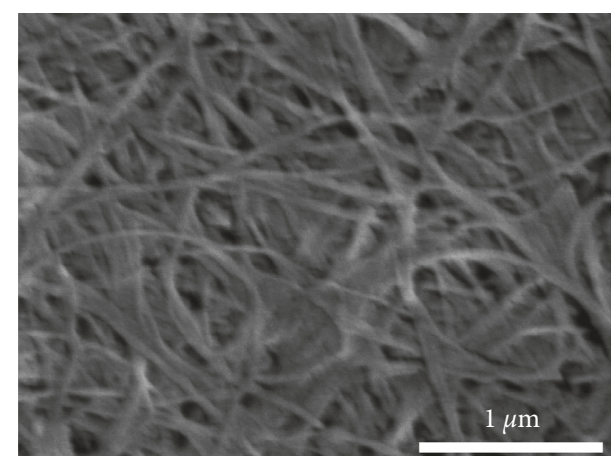

(b)

FIgURE 9: $35 \mathrm{k}$ magnification of SEM images of (a) DNDC (A0) and (b) OC-24 hrs (A4).

and OC-48 hrs (D4) was 65.4, 64.2, 63.5, 60.5, and $58.3 \mathrm{~nm}$, respectively. The diameter size decreased with an increase of the reaction time because of the hydrolysis of the raw material by strong acid. This is a reason to support that the $\%$ yield of the OC decreased with an increase of reaction time.

On the contrary, the morphology of the fiber of the natural cotton linter and $\mathrm{OC}$ from cotton were also analyzed by SEM at $10 \mathrm{kV}$ but using $100 \mathrm{x}$ magnifications. The SEM images and diameter size distribution from SEM images of the natural cotton linter and $\mathrm{OC}$ from natural cotton linter are shown in Figure 10. The diameter of the natural cotton linter also decreased after oxidation reaction. The average diameter of the natural cotton linter was $17.3 \mu \mathrm{m}$, and their natural cotton linter oxidized for $6,12,24,36$, and 48 hours was $16.4,16.4,15.0,14.3$, and $12.7 \mu \mathrm{m}$, respectively. It should be noted that the diameter of the cellulose fiber of Nata De Coco was significantly smaller than that of the natural cotton linter.

3.5. X-Ray Diffraction Analysis. X-ray diffraction patterns of DNDC (A0) and the OC products are shown in Figure 11. 

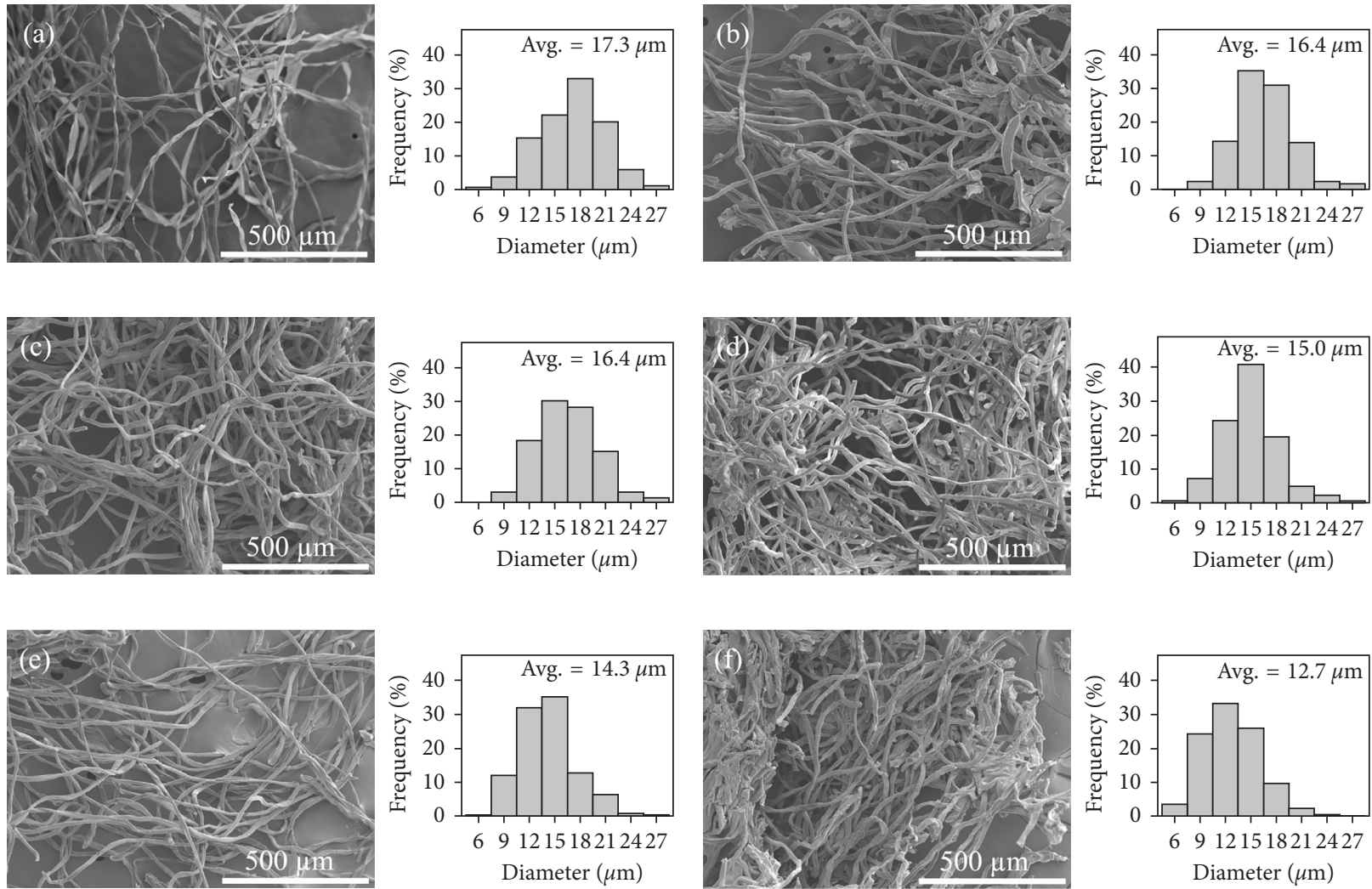

Figure 10: SEM images of (a) natural cotton linter and oxidized natural cotton linter for (b) F1, (c) F2, (d) F3, (e) F4, and (f) F5 and their diameter size distribution.

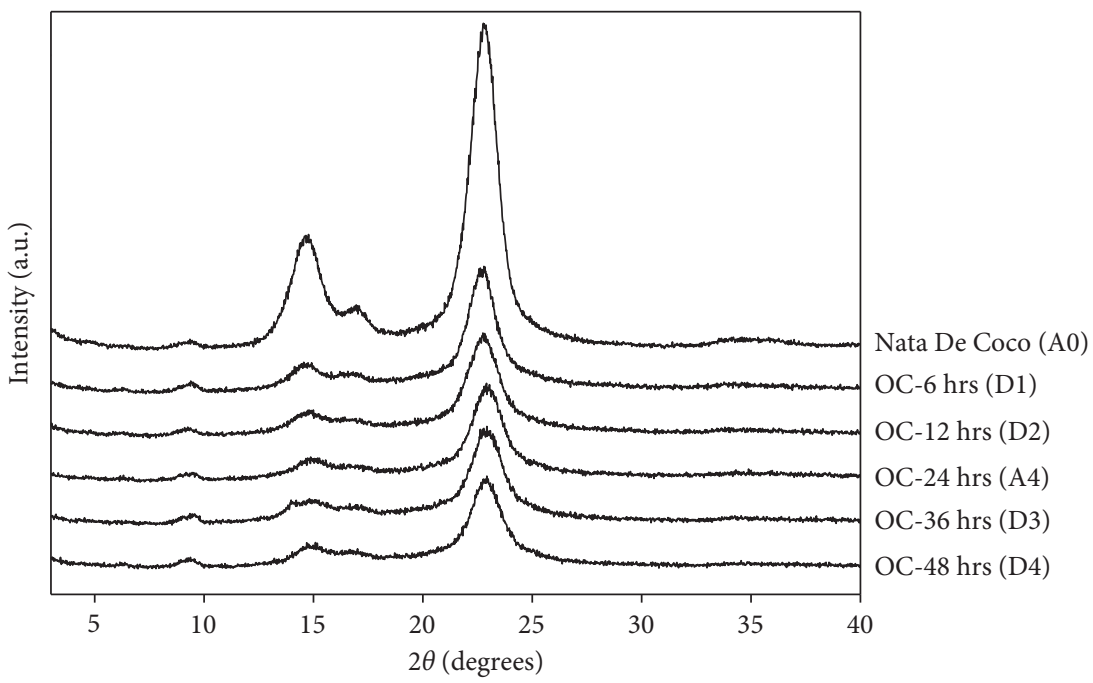

Figure 11: X-ray diffraction patterns of DNDC (A0) and the OC products.

The diffraction patterns of the OC product were similar with the raw material of DNDC (A0). All of the patterns showing three distinct peaks at $2 \theta=14.6^{\circ}, 16.8^{\circ}$, and $22.9^{\circ}$ were, respectively, attributed to the ( $\left(\begin{array}{lll}1 & 0 & 1\end{array}\right),\left(\begin{array}{lll}1 & 0 & \overline{1}\end{array}\right)$, and $\left(\begin{array}{lll}0 & 0 & 2\end{array}\right)$ reflection planes of the typical cellulose I structure $[34,35]$.

In addition, characteristic peaks, crystallinity $\left(X_{c}\right)$, and crystalline index (CrI) are shown in Table 2. The location of the characteristic peak of the OC products did not particularly change from the raw material of DNDC (A0). It could be concluded that the crystalline form did not change from $\mathrm{HNO}_{3} / \mathrm{H}_{3} \mathrm{PO}_{4}-\mathrm{NaNO}_{2}$ oxidation process. However, the crystallinity and crystalline index of the OC products showed remarkable decrease from the raw material of DNDC (A0). With an increase of reaction time, the decrease 
TABLE 2: Characteristic peaks and crystalline parameters of DNDC (A0) and the OC products.

\begin{tabular}{|c|c|c|c|c|c|}
\hline \multirow{2}{*}{$\begin{array}{l}\text { Sample } \\
\text { DNDC (A0) }\end{array}$} & \multicolumn{3}{|c|}{$\begin{array}{c}\text { Location of characteristic peak, } 2 \theta \\
\text { (degrees) }\end{array}$} & \multirow{2}{*}{$\begin{array}{c}\text { Crystallinity (\%) } \\
89.29\end{array}$} & \multirow{2}{*}{$\begin{array}{c}\text { Crystalline index (\%) } \\
92.65\end{array}$} \\
\hline & 22.84 & 16.76 & 14.63 & & \\
\hline OC-6hrs (D1) & 22.90 & 16.84 & 14.60 & 78.23 & 83.31 \\
\hline OC-12 hrs (D2) & 22.75 & 16.90 & 14.54 & 77.20 & 80.32 \\
\hline OC-24hrs (A4) & 22.95 & 16.73 & 14.51 & 76.01 & 79.64 \\
\hline OC-36 hrs (D3) & 22.92 & 16.79 & 14.54 & 74.94 & 79.56 \\
\hline OC- 48 hrs (D4) & 22.86 & 16.73 & 14.80 & 71.34 & 79.40 \\
\hline
\end{tabular}

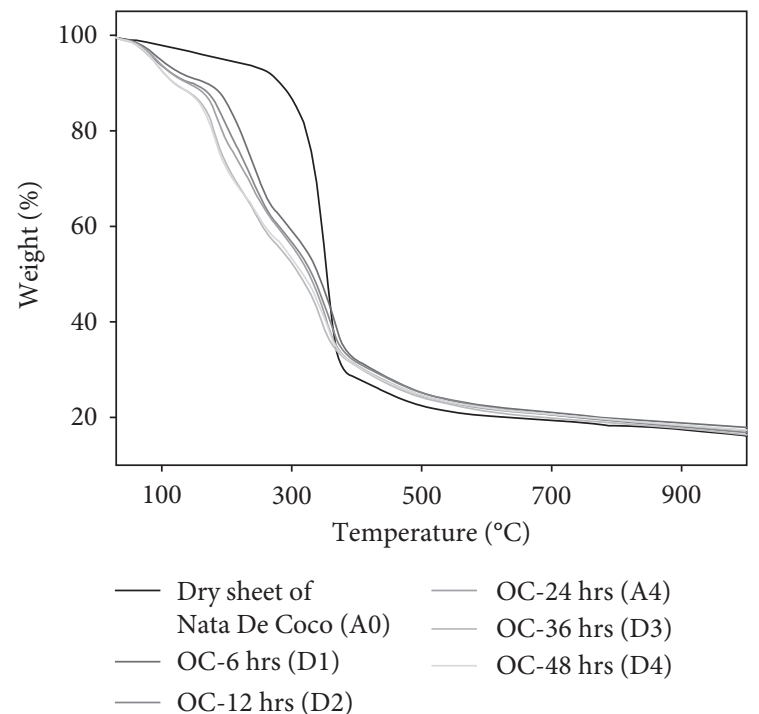

(a)

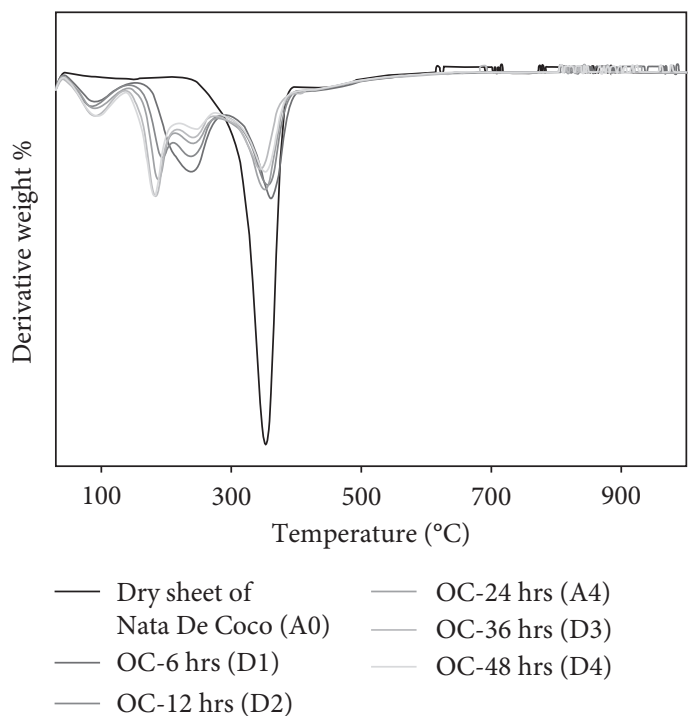

(b)

Figure 12: (a) TGA and (b) DGTA curves of DNDC (A0) and the OC products.

TABLE 3: Thermal gravimetric data of DNDC (A0) and the OC products.

\begin{tabular}{lcccc}
\hline Sample & \multicolumn{4}{c}{$\begin{array}{c}\text { Degradation } \\
\text { temperature } \\
\left({ }^{\circ} \mathrm{C}\right)\end{array}$} \\
& $\begin{array}{c}\text { Volatile } \\
\text { content (\%) }\end{array}$ & $\begin{array}{c}\text { Weight loss at } \\
\text { Initial } \\
\text { stage }\end{array}$ & $\begin{array}{c}\text { Final } \\
\text { stage }\end{array}$ & final stage (\%) \\
\hline DNDC (A0) & 5.74 & 348 & - & 77.99 \\
OC-6 hrs (D1) & 9.14 & 218 & 351 & 72.85 \\
OC-12 hrs (D2) & 9.68 & 186,223 & 345 & 72.80 \\
OC-24 hrs (A4) & 9.87 & 182,220 & 341 & 72.73 \\
OC-36 hrs (D3) & 11.73 & 178,223 & 334 & 71.83 \\
OC-48 hrs (D4) & 11.79 & 176,223 & 339 & 70.71 \\
\hline
\end{tabular}

of crystallinity and crystalline index become slower because the first stage of oxidation reaction occurs on the amorphous region and crystalline region surfaces of cellulose. Then, the oxidation reaction sluggishly penetrates into the crystalline region and destroyed the crystalline structure of cellulose gradually [8].

3.6. Degree of Polymerization (DP). The DP of DNDC (A0) was about $1,126.6$, while the DP of the OC products as OC$6 \mathrm{hrs}$ (D1), OC-12 hrs (D2), OC-24 hrs (A4), OC-36 hrs
(D3), and OC-48 hrs (D4) was 94.6, 76.3, 74.1, 73.7, and 67.7, respectively. The DP of the OC products showed a significant decrease from the raw material of DNDC (A0) because of depolymerization of the cellulosic material by strong acid. Moreover, DP of the OC product decreased with increase of reaction time suggesting that the hydrolysis of the $\beta-1,4-$ glycosidic linkages in the cellulose structure increased with an increase of reaction time.

3.7. Thermal Analysis. TGA and DGTA curves of DNDC (A0) and the OC products are shown in Figure 12, and thermal gravimetric data are also shown in Table 3. All samples showed a weight loss due to the volatile content on the surface evaporation between 40 and $125^{\circ} \mathrm{C}$, and the volatile content increased with an increase of reaction time because the sample with higher carboxyl content had the greater affinity for molecules of water [10]. The initial degradation temperature of the raw material of DNDC (A0) was about $348^{\circ} \mathrm{C}$, which is in the same range with degradation temperature of bacterial cellulose in the previous report [34-36], due to dehydration and decomposition of the cellulose molecules. The initial degradation temperature of the OC products was lower than that of DNDC (A0). Moreover, the decomposition patterns became more complex for OC products. The first step of degradation 

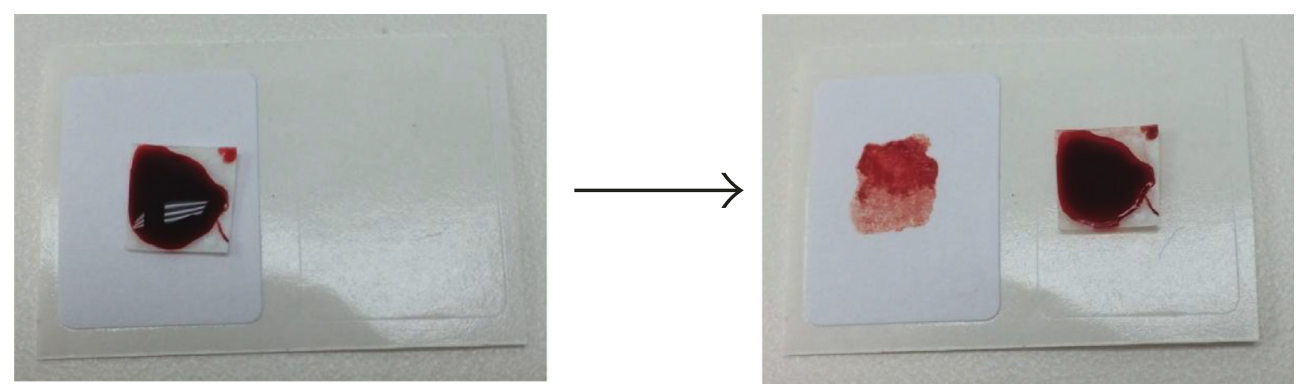

(a)
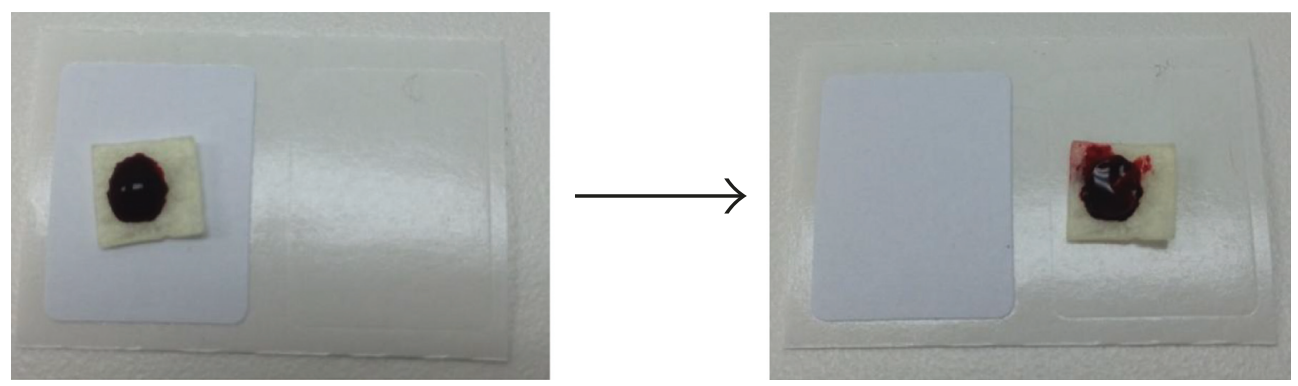

(b)

FIgUre 13: Agglutination of the blood test of (a) DNDC (A0) and (b) OC-24 hrs (A4).

temperature was approximately $176-223^{\circ} \mathrm{C}$, and the final state was approximately $223-334^{\circ} \mathrm{C}$ due to the degradation of the remaining residue. The thermal stability and weight loss of the OC products are likely to decrease with an increase reaction time.

3.8. Agglutination of Blood Test. The results of agglutination of the blood test on DNDC (A0) and OC-24 hrs (A4) are shown in Figure 13. The thickness of DNDC (A0) and OC$24 \mathrm{hrs}$ (A4) were 0.15 and $0.19 \mathrm{~mm}$, respectively. The DNDC (A0) and OC-24hrs (A4) were placed on an inspection paper. Then, a drop of blood sample was placed on the testing sample, and let to stand for 10 minutes. The blood stain was found on the inspection paper after removing the testing sample for DNDC (A0), while the blood stain was not found in OC-24hrs (A4). Moreover, the blood sample on OC-24 hrs (A4) turned into dark brown or black gel. From the results, it could be concluded that the OC have the blood agglutinating property due to the activation of platelets and the artificial clot formation by combining between the $\mathrm{Fe}^{3+}$ ions in the blood and carboxyl groups of OC [9].

3.9. Antibacterial Activity. The antibacterial activity tests of DNDC (A0) and OC-24 hrs (A4) are shown in Table 4. The antibacterial performance of OC-24hrs (A4), which was evaluated by means of Gram-negative bacterium Escherichia coli ATCC 25922 as representative, indicated that the reduction of CFU exceeds $99.99 \%$, while the antibacterial activity property was not observed in DNDC (A0). It should be concluded that the OC possesses bactericidal activity [37].
TABLE 4: Antibacterial activity test of DNDC (A0) and the OC24 hrs (A4).

\begin{tabular}{lcccc}
\hline Test organisms & $\begin{array}{c}\text { Inoculum } \\
\text { size } \\
(\mathrm{CFU} / \mathrm{mL})\end{array}$ & Sample & $\begin{array}{c}\text { Number } \\
(\mathrm{CFU} / \mathrm{mL})\end{array}$ & $\begin{array}{c}\% \\
\text { reduction }\end{array}$ \\
\hline Escherichia coli & $1.59 \times 10^{5}$ & $\begin{array}{c}\text { DNDC } \\
\text { (A0) } \\
\text { OC-24hrs } \\
\text { ATCC 25922 }\end{array}$ & $1.58 \times 10^{5}$ & - \\
& & (A4) & $\leq 10$ & 99.99 \\
\hline
\end{tabular}

\section{Conclusions}

The results showed that the OC nanofiber was prepared from DNDC with high \% yield by a reaction using a mixture of the $\mathrm{HNO}_{3} / \mathrm{H}_{3} \mathrm{PO}_{4}-\mathrm{NaNO}_{2}$ system. It was found that the $\mathrm{OC}$ from the reaction at $30^{\circ} \mathrm{C}$ by using $\mathrm{HNO}_{3} / \mathrm{H}_{3} \mathrm{PO}_{4}=1: 3$ of acid mixture and $1.4 \%(\mathrm{w} / \mathrm{v})$ of $\mathrm{NaNO}_{2}$ for 24 hours was the optimum condition for synthesis of the OC. The reaction yielded $83.19 \%$ of OC with $20.93 \%$ of carboxyl content. Moreover, the diameter of the fiber showed a great effect on the carboxyl content and \% yield. It was found that the carboxyl content and \% yield of the OC from DNDC (A0) was higher than those of the OC from the cotton linter at the same oxidizing condition.

Based on a structural analysis, the OC products showed a nanofibrous structure with a diameter about $58.3-65.4 \mathrm{~nm}$, and the diameter of the fiber decreased gradually with increasing oxidation extent due to the hydrolysis of fiber by strong acid. The FT-IR spectra of the OC products clearly showed a new absorption peak at $1724 \mathrm{~cm}^{-1}$ from the vibration of $-\mathrm{C}=\mathrm{O}$, which suggested the formation of carboxyl groups after the oxidation reaction. The decrease of crystallinity from oxidation process agreed with the decrease of 
degree of polymerization from the hydrolysis of $\beta-1,4$ glycosidic linkages in the cellulose structure. The TG and DTG results of OC products showed a weight loss between 40 and $125^{\circ} \mathrm{C}$ due to the volatile content on the surface evaporation. The result revealed the $\mathrm{OC}$ products to be less thermally stable than the DNDC (A0).

In addition, the obtained products showed the blood agglutinating property by dropping blood on the sample test and also showed excellent antibacterial activity, thus the reduction of CFU exceeds $99.99 \%$ of Escherichia coli ATCC 25922. It shows that the novel OC nanofiber from Nata De Coco has a good potential for further applications such as the medical material or antibacterial material [38-40].

\section{Data Availability}

The data used to support the findings of this study are available from the corresponding author upon request.

\section{Conflicts of Interest}

The authors declare that there are no conflicts of interest regarding the publication of this paper.

\section{Acknowledgments}

The authors gratefully acknowledge the financial support provided by Thammasat University Research Fund under the TU Research Scholar, Contract no. 57/2557.

\section{References}

[1] J. Barnard and R. Millner, "A review of topical hemostatic agents for use in cardiac surgery," Annals of Thoracic Surgery, vol. 88, no. 4, pp. 1377-1383, 2009.

[2] M. Amit, Y. Binenbaum, J. T. Cohen, and Z. Gil, "Effectiveness of an oxidized cellulose patch hemostatic agent in thyroid surgery: a prospective, randomized, controlled study," Journal of the American College of Surgeons, vol. 217, no. 2, pp. 221-225, 2013.

[3] J. B. Sharma, M. Malhotra, and P. Pundir, "Laparoscopic oxidized cellulose (surgical) application for small uterine perforations," International Journal of Gynecology and $\mathrm{Ob}$ stetrics, vol. 83, no. 3, pp. 217-275, 2003.

[4] J. B. Sharma and M. Malhotra, "Topical oxidized cellulose for tubal hemorrhage hemostasis during laparoscopic sterilization," International Journal of Gynecology and Obstetrics, vol. 82, no. 3, pp. 221-222, 2003.

[5] L. Zhu, V. Kumar, and G. S. Banker, "Examination of oxidized cellulose as a macromolecular prodrug carrier: preparation and characterization of an oxidized cellulose-phenylpropanolamine conjugate," International Journal of Pharmaceutics, vol. 223, no. 1-2, pp. 35-47, 2001.

[6] N. Isobe, X. Chen, U. J. Kim et al., "TEMPO-oxidized cellulose hydrogel as a high-capacity and reusable heavy metal ion adsorbent," Journal of Hazardous Materials, vol. 260, pp. 195-201, 2013.

[7] T. Saito and A. Isogai, "Ion-exchange behavior of carboxylate groups in fibrous cellulose oxidized by the TEMPO-mediated system," Carbohydrate Polymers, vol. 61, no. 4, pp. 183-190, 2005.
[8] Y. D. Wu, J. M. He, Y. D. Huang, F. W. Wang, and F. Tang, "Oxidation of regenerated cellulose with nitrogen dioxide/ carbon tetrachloride," Fiber and Polymers, vol. 13, no. 5, pp. 576-581, 2012.

[9] Y. Wu, J. He, W. Cheng et al., "Oxidized regenerated cellulose-based hemostat with microscopically gradient structure," Carbohydrate Polymers, vol. 88, no. 3, pp. 1023$1032,2012$.

[10] V. Kumar and T. Yang, " $\mathrm{HNO}_{3} / \mathrm{H}_{3} \mathrm{PO}_{4}-\mathrm{NANO}_{2}$ mediated oxidation of cellulose-preparation and characterization of bioabsorbable oxidized cellulose in high yields and with different levels of oxidation," Carbohydrate Polymers, vol. 48, no. 4, pp. 403-412, 2002.

[11] Y. Xu, X. Liu, X. Liu, J. Tan, and H. Zhu, "Influence of $\mathrm{HNO}_{3}$ / $\mathrm{H}_{3} \mathrm{PO}_{4}-\mathrm{NANO}_{2}$ mediated oxidation on the structure and properties of cellulose fibers," Carbohydrate Polymers, vol. 111, pp. 955-963, 2014.

[12] P. Ma, S. Fu, H. Zhai, and C. Daneault, "Influence of TEMPOmediated oxidation on the lignin of thermomechanical pulp," Bioresource Technology, vol. 118, pp. 607-610, 2012.

[13] T. Saito, Y. Okita, T. T. Nge, and J. Sugiyama, “TEMPOmediated oxidation of native cellulose: microscopic analysis of fibrous fractions in the oxidized product," Carbohydrate Polymers, vol. 65, no. 4, pp. 435-440, 2006.

[14] G. Biliuta, L. Fras, M. Drobota et al., "Comparison study of TEMPO and phthalimide- $N$-oxyl (PINO) radicals on oxidation efficiency toward cellulose," Carbohydrate Polymers, vol. 91, no. 2, pp. 502-507, 2013.

[15] C. Ververis, K. Georghiou, N. Christodoulakis, P. Santas, and R. Santas, "Fiber dimensions, lignin and cellulose content of various plant materials and their suitability for paper product," Industrial Crops and Products, vol. 19, no. 3, pp. 245-254, 2004.

[16] N. Halib, M. C. I. Amin, and I. Ahmad, "Physicochemical properties and characterization of Nata de Coco from local food industries as a source of cellulose," Sains Malaysiana, vol. 41, no. 2, pp. 205-211, 2012.

[17] Y. Kaburagi, M. Ohoyama, Y. Yamaguchi et al., "Graphitization behavior of carbon nanofibers derived from bacteria cellulose," Carbon, vol. 55, pp. 371-374, 2013.

[18] E. L. Hult, S. Yamanaka, M. Ishihara, and J. Sugiyama, "Aggregation of ribbons in bacterial cellulose induced by high pressure incubation," Carbohydrate Polymers, vol. 53, no. 1, pp. 9-14, 2003.

[19] D. Klemm, D. Schumann, U. Udhardt, and S. Marsch, "Bacterial synthesized cellulose-artificial blood vessels for microsurgery," Progress in Polymer Science, vol. 26, no. 9, pp. 1561-1603, 2001.

[20] X. D. Cao, H. Dong, and C. M. Li, "New nanocomposite materials reinforced with flax cellulose nanocrystals in waterborne polyurethane," Biomacromolecules, vol. 8, no. 3, pp. 899-904, 2007.

[21] K. Das, D. Ray, C. Banerjee et al., "Physicomechanical and thermal properties of jute nanofiber reinforced biocopolyester composites," Industrial and Engineering Chemistry Research, vol. 49, no. 6, pp. 2775-2782, 2010.

[22] H. Dong, K. E. Strawheckera, J. F. Snydera et al., "Cellulose nanocrystals as a reinforcing material for electrospun poly (methyl methacrylate) fibers: formation, properties and nanomechanical characterization," Carbohydrate Polymers, vol. 87, no. 4, pp. 2488-2495, 2012.

[23] P. Lu and Y. L. Hsieh, "Cellulose nanocrystal-filled poly (acrylic acid) nanocomposite fibrous membranes," Nanotechnology, vol. 20, no. 41, p. 415604, 2009. 
[24] H. Deng, X. Zhou, X. Wang et al., "Layer-by-layer structured polysaccharides film-coated cellulose nanofibrous mats for cell culture," Carbohydrate Polymers, vol. 80, no. 2, pp. 475480, 2010.

[25] P. Ross, M. Raphae, and P. Moshe, "Cellulose biosynthesis and function in bacteria," Microbiology Review, vol. 55, pp. 35-38, 1991.

[26] A. Kurosumi, C. Sasaki, Y. Yamashita, and Y. Nakamura, "Utilization of various fruit juices as carbon source for production of bacterial cellulose by Acetobacter xylinum NBRC 13693," Carbohydrate Polymers, vol. 76, no. 2, pp. 333-335, 2009.

[27] USP, United States Pharmacopeia 23/National Formulary 18: Oxidized Cellulose, USP, Rockville, MD, USA, 1995.

[28] S. Park, J. O. Baker, M. E. Himmel, P. A. Parilla, and D. K. Johnson, "Cellulose crystallinity index: measurement techniques and their impact on interpreting cellulose performance," Biotechnology and Biofuels, vol. 3, no. 1, pp. 1-10, 2010.

[29] ASTM D 1795-96, Standard Test Method for Intrinsic Viscosity of Cellulose, ASTM, West Conshohocken, PA, USA, 2001.

[30] V. Khatri, K. Halász, L. V. Trandafilović et al., "ZnO-modified cellulose fiber sheets for antibody immobilization," Carbohydrate Polymers, vol. 109, pp. 139-147, 2014.

[31] P. Jarujamrus, J. Tian, X. Li et al., "Mechanisms of red blood cells agglutination in antibody-treated paper," Analyst, vol. 137, no. 9, pp. 2205-2210, 2012.

[32] M. Li, J. Tian, M. Al-Tamimi, and W. Shen, "Paper-based blood typing device that report patient's blood type "in writing"," Angewandte Chemie International Edition, vol. 51, no. 22, pp. 5497-5501, 2012.

[33] ASTM E2149, Standard Test Method for Determining the Antimicrobial Activity of Antimicrobial Agent under Dynamic Control Conditions, ASTM, West Conshohocken, PA, USA, 2013.

[34] Q. Gao, X. Shen, and X. Lu, "Regenerated bacterial cellulose fiber prepared by the NMMO $\cdot \mathrm{H}_{2} \mathrm{O}$ process," Carbohydrate Polymers, vol. 83, no. 3, pp. 1253-1256, 2011.

[35] X. Lu and X. Shen, "Solubility of bacteria cellulose in zinc chloride aqueous solutions," Carbohydrate Polymers, vol. 86, no. 1, pp. 239-244, 2011.

[36] J. A. Marins, B. G. Soares, H. S. Barud, and S. J. L. Ribeiro, "Flexible magnetic membranes based on bacterial cellulose and its evaluation as electromagnetic interference shielding material," Materials Science and Engineering C, vol. 33, no. 7, pp. 3994-4001, 2013.

[37] P. R. Murray, K. S. Rosenthal, G. S. Kobayashi, and M. A. Pfaller, Bacteriology, Medical Biomicrobiology, A Harcourt Health Sciences Company, London, UK, 4th edition, 2002.

[38] W. Huang, X. Li, Y. Xue et al., "Antibacterial multilayer films fabricated by LBL immobilizing lysozyme and HTCC on nanofibrous mats," International Journal of Biological Macromolecules, vol. 53, pp. 26-31, 2013.

[39] J. M. He, Y. D. Wu, F. W. Wang et al., "Hemostatic, antibacterial and degradable performance of the water-soluble chitosan-coated oxidized regenerated cellulose gauze," Fiber and Polymers, vol. 15, no. 3, pp. 504-509, 2014.

[40] A. Maleki, H. Movahed, and R. Paydar, "Design and development of a novel cellulose/gamma-Fe2O3/Ag nanocomposite: a potential green catalyst and antibacterial agent," RSC Advances, vol. 6, no. 17, pp. 13657-13665, 2016. 


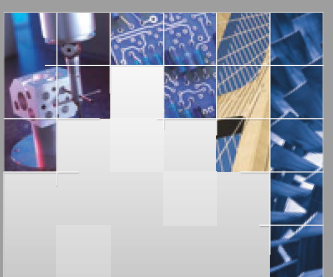

\section{Enfincering}
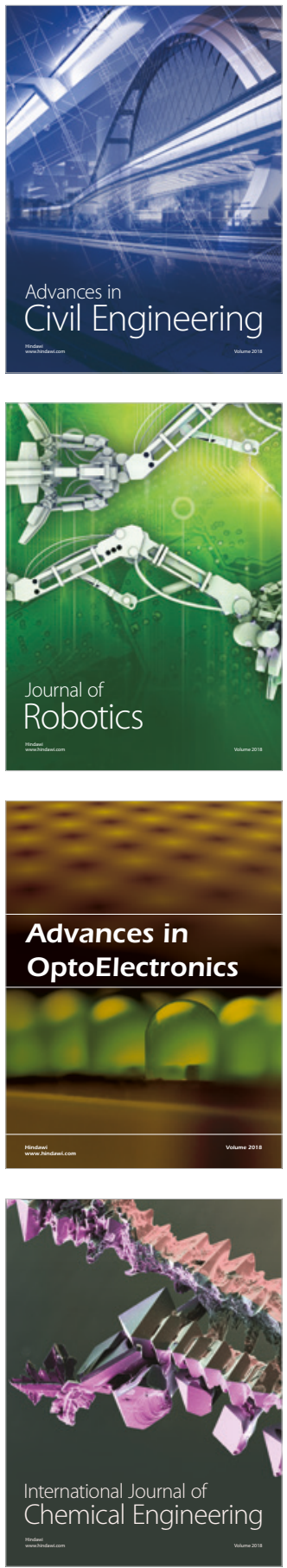

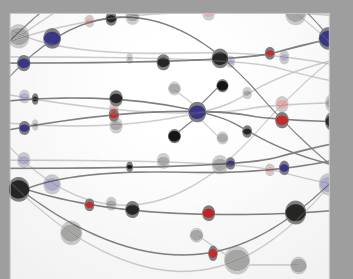

\section{Rotating \\ Machinery}

The Scientific World Journal

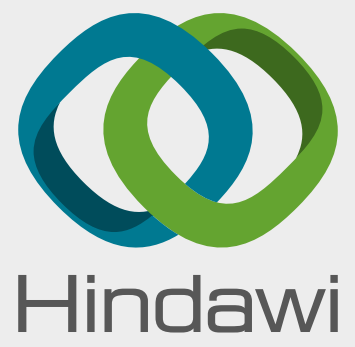

Submit your manuscripts at

www.hindawi.com
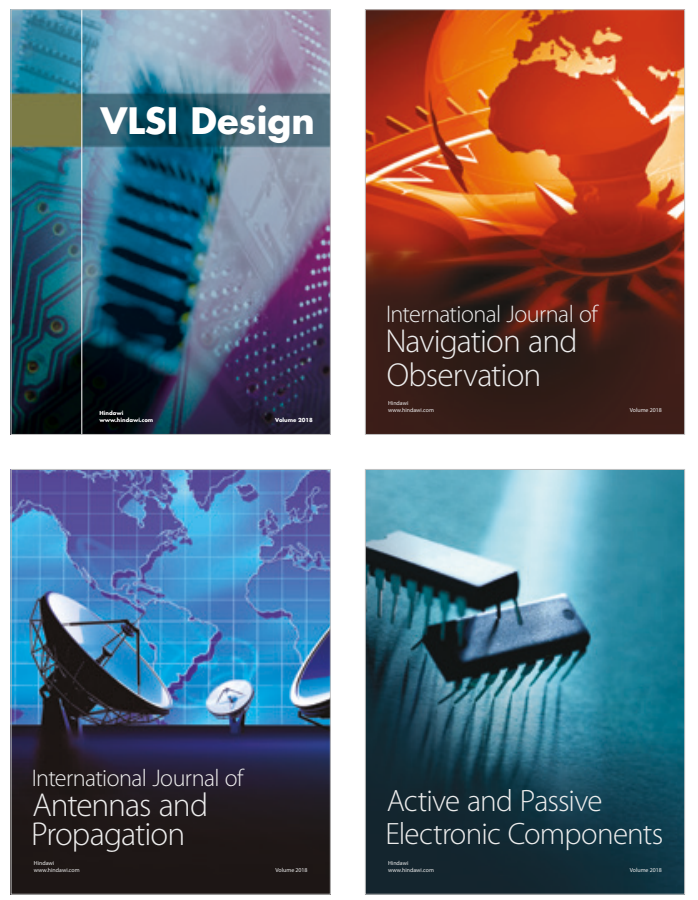
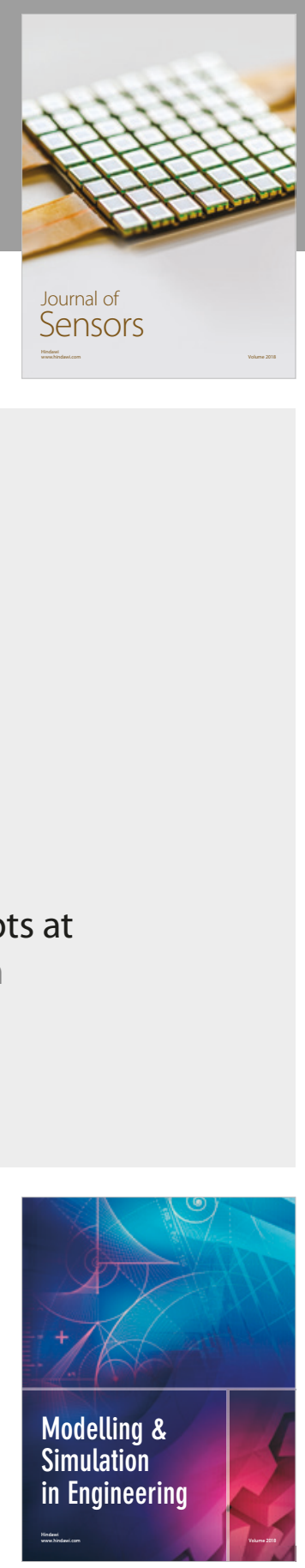

\section{Advances \\ Multimedia}
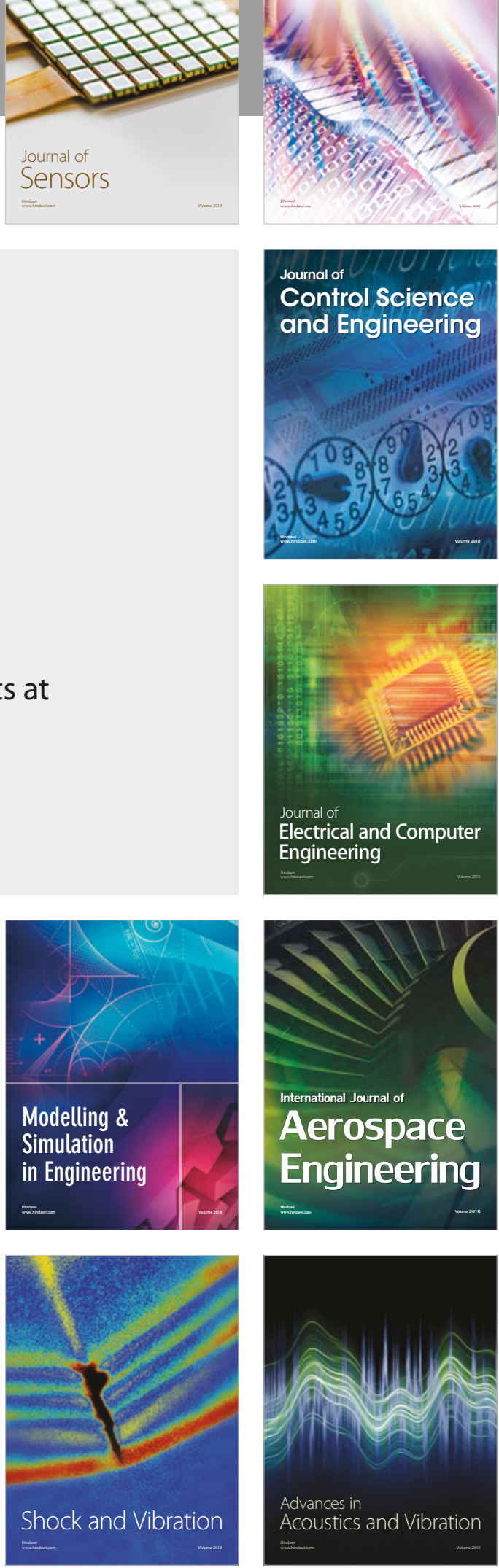